\title{
Anaerobic Co-Digestion of Wastewater Sludge: A Review of Potential Co-Substrates and Operating Factors for Improved Methane Yield
}

\author{
Wei Ling Chow ${ }^{1}$, Siewhui Chong ${ }^{1}{ }^{(}$, Jun Wei Lim $\left.{ }^{2}{ }^{(}\right)$, Yi Jing Chan ${ }^{1} * \mathbb{D}^{\circ}$, Mei Fong Chong ${ }^{3}$, \\ Timm Joyce Tiong ${ }^{1}$, Jit Kai Chin ${ }^{4}\left(\mathbb{D}\right.$ and Guan-Ting Pan ${ }^{5, *}$ \\ 1 Department of Chemical and Environmental Engineering, University of Nottingham Malaysia, Broga Road, \\ Semenyih 43500, Selangor Darul Ehsan, Malaysia; Weiling.chow@hotmail.co.uk (W.L.C.); \\ Faye.chong@nottingham.edu.my (S.C.); Joyce.tiong@nottingham.edu.my (T.J.T.) \\ 2 Department of Fundamental and Applied Sciences, Centre for Biofuel and Biochemical Research, \\ Institute of Self-Sustainable Building, Universiti Teknologi PETRONAS, Seri Iskandar 32610, \\ Perak Darul Ridzuan, Malaysia; Junwei.lim@utp.edu.my \\ 3 28, Jalan Pulau Tioman U10/94, Taman Greenhill, Shah Alam 40170, Selangor Darul Ehsan, Malaysia; \\ Chong_mei_fong@yahoo.com \\ 4 Department of Chemical Sciences, School of Applied Sciences, University of Huddersfield, Queensgate, \\ Huddersfield HD1 3DH, UK; J.chin@hud.ac.uk \\ 5 Department of Chemical Engineering and Biotechnology, National Taipei University of Technology, No. 1, \\ Section 3, Zhongxiao E Rd, Da'an District, Taipei City 106, Taiwan \\ * Correspondence: Yi-jing.chan@nottingham.edu.my (Y.J.C.); Gtpan@ntut.edu.tw (G.-T.P.); \\ Tel.: +60-3-8924-8773 (Y.J.C.); +886-2-2771-2171 (G.-T.P.)
}

Received: 20 August 2019; Accepted: 20 September 2019; Published: 1 January 2020

\begin{abstract}
Anaerobic digestion has been widely employed in waste treatment for its ability to capture methane gas released as a product during the digestion. Certain wastes, however, cannot be easily digested due to their low nutrient level insufficient for anaerobic digestion, thus co-digestion is a viable option. Numerous studies have shown that using co-substrates in anaerobic digestion systems improve methane yields as positive synergisms are established in the digestion medium, and the supply of missing nutrients are introduced by the co-substrates. Nevertheless, large-scale implementation of co-digestion technology is limited by inherent process limitations and operational concerns. This review summarizes the results from numerous laboratory, pilot, and full-scale anaerobic co-digestion (ACD) studies of wastewater sludge with the co-substrates of organic fraction of municipal solid waste, food waste, crude glycerol, agricultural waste, and fat, oil and grease. The critical factors that influence the ACD operation are also discussed. The ultimate aim of this review is to identify the best potential co-substrate for wastewater sludge anaerobic co-digestion and provide a recommendation for future reference. By adding co-substrates, a gain ranging from 13 to $176 \%$ in the methane yield was accomplished compared to the mono-digestions.
\end{abstract}

Keywords: anaerobic digestion; co-digestion; wastewater; biogas production; methane yield, sludge

\section{Introduction}

Many industries face difficulties in treating their high-strength wastewaters. These wastewaters usually consist of a high chemical oxygen demand (COD) of more than 10,000 mg/L, or biochemical oxygen demand (BOD) of more than $5000 \mathrm{mg} / \mathrm{L}$. For instance, pineapple industrial wastewater and palm oil mill effluent, generated at a rate of 0.5 to 0.75 tonnes per tonne of fresh fruit bunch, have a COD of 50,000-80,000 mg/L [1,2]. These high-strength wastewaters need to undergo a series of treatment 
processes to meet the local allowable discharge limits. Anaerobic co-digestion (ACD) has been recognized as an effective effluent treatment for industrial wastes, due to its ability to counter-balance nutrient insufficiency and economic feasibility. ACD is a process of adding energy rich organic waste materials to wastewater digesters in the absence of oxygen, as bacteria break down organic materials and produce biogas. The most common processes involve a major amount of a main basic substrate, for example, manure or sewage sludge, which is mixed and digested together with minor amounts of a single, or a variety of additional substrate [3].

ACD has strong potential to contribute to both pollution control and energy recovery. One of the major advantages of ACD is that it increases the efficiency of organic waste degradation and thus biogas production. The capture of methane, which can be used as an energy source, is contributed by diverting the wastes from landfills to wastewater treatment facilities. Co-digestion also forms an ideal nutrient balance resulting in an increase of digestion performance and biogas yields. Because of the use of co-substrates, which establish positive synergisms in the digestion medium, and act as a supplier of missing nutrients, biogas yields are found to be improved from mono-digestion $[4,5]$. In addition, co-digestion gives a diversion opportunity to reduce landfill space, besides aiding most municipalities to achieve their recovery goals. Therefore, wastewater treatment facilities can expect to see a cost savings from incorporating wastes into anaerobic digesters with mono-digestion systems. These include reduced-energy costs resulting from production of on-site power from biogas yields.

While there have been many studies on the advantages of ACD over mono-digestion [6], and its effective outcome in treating waste, little to no research has reviewed the feasibility of various co-substrates associated with their influential factors on co-digestion, and their optimum operating conditions. Although co-digestion carries numerous benefits, many researchers have still encountered difficulties in performing co-digestion, which have sometimes led to system upset, mainly due to inappropriate substrate ratios and operating conditions. This challenge was demonstrated by Wan, et al. [7], who reported a digestion failure when adding 75\% or more of fat, oil and grease feed, which may have caused acidification of the digester. This is also supported by Astals, et al. [8], who reported system upset resulting in low methane yield when incorporating more than $4 \%$ of crude glycerol into the digester. Wan, et al. [7] further added that a relatively short hydraulic retention time (HRT) of ten days employed might also contribute to the digestion failure, due to washout of microorganisms during removal of treated wastewater.

Despite the possible disadvantages of ACD, which likely have occurred through lack of knowledge of ACD practice, this review discusses how results from numerous laboratory, pilot, and full-scale ACD studies can be used to address the feasibility and potential of different co-substrates used for ACD using domestic wastewater sludge as the main substrate. The review starts with the summaries and discussions of the anaerobic co-digestion results from recent literature, and ends with a comparative analysis to identify the best co-substrate for the ACD of wastewater sludge. At the end, a recommendation on how the anaerobic co-digestion can be integrated into a wastewater treatment plant (WWTP) is presented. This review aims to serve as a guideline for other researchers to achieve optimum operating conditions for co-digestion leading to minimal operational problems and maximum biogas production.

\section{Potential Co-Substrates for Anaerobic Co-Digestion of Wastewater Sludge}

In a wastewater treatment plant, wastewater sludge such as sewage sludge, waste activated sludge, and thickened waste activated sludge, are usually sent to an anaerobic digester to remove solids and generate biogas. As shown in Table 1, the potential co-substrates used in anaerobic co-digestion of wastewater sludge are identified to be the organic fraction of municipal solid wastes (OFMSW), food waste (FW), agricultural wastes (AW), crude glycerol (CG), and fat, oil and grease (FOG). In order to achieve the optimal carbon-to-nitrogen $(\mathrm{C} / \mathrm{N})$ ratio for anaerobic digestion, which is around 20-30 [9], wastewater sludge with a low $\mathrm{C} / \mathrm{N}$ ratio of 6-10 can be co-digested with the co-substrate with a higher $\mathrm{C} / \mathrm{N}$ ratio to counterbalance the nutrients and avoid inhibition that leads to system instability. 
Table 1. Carbon-to-nitrogen $(\mathrm{C} / \mathrm{N})$ ratio of the primary and co-substrates reviewed in this study.

\begin{tabular}{cccc}
\hline Common Primary Wastewater Substrates & & C/N Ratio & Ref. \\
\hline Sewage sludge (SS) & & $6-10$ & {$[10]$} \\
Waste activated sludge (WAS) & 10 & {$[11]$} \\
Thickened waste activated sludge (TWAS) & & $6-9$ & {$[12]$} \\
\hline Common Co-Substrates & Example & C/N Ratio & Ref. \\
\hline Organic fraction of municipal solid wastes (OFMSW) & & $11-21$ & {$[13]$} \\
Food waste (FW) & & $11-15$ & {$[14]$} \\
Agricultural wastes (AW): & Rice straw & $50-53$ & {$[12]$} \\
& Potatoes & $35-60$ & {$[12]$} \\
& Corn stalks/straw & $50-56$ & {$[12]$} \\
& Sugar cane/bagasse & $140-150$ & {$[12]$} \\
& Sugar beet & $35-40$ & {$[12]$} \\
Crude glycerol (CG) & Grass/trimmings & $12-16$ & {$[12]$} \\
Fat, oil and grease (FOG) & Fallen leaves & $50-53$ & {$[12]$} \\
& Horse manure & $20-25$ & {$[12]$} \\
& Pig manure & $6-14$ & {$[12]$} \\
& Cow dung & $16-25$ & {$[12]$} \\
& & 68 & {$[15]$} \\
& & 22 & {$[7]$} \\
\hline
\end{tabular}

\subsection{Organic Fraction of Municipal Solid Waste (OFMSW) and Food Waste (FW)}

Municipal solid waste consists of diverse, discarded items such as product packaging, grass clippings, furniture, clothing, bottles, food scraps, newspapers, appliances, paint, and batteries, originating from residential, commercial and institutional locations [16]. The U.S. Environmental Protection Agency's (EPA) definition of municipal solid waste, however, does not include industrial, hazardous, or construction and demolition waste [16]. The organic fraction of municipal solid waste on the other hand, can be defined as the biodegradable fraction consisting of food waste, kitchen waste, leaf, grass clippings, flower trimmings and yard waste, of which food waste occupies the highest proportion [17].

The $\mathrm{C} / \mathrm{N}$ ratio of OFMSW is around 11-21, and moisture content around $70-82 \%$ [13]; whereas for food waste, the $\mathrm{C} / \mathrm{N}$ ratio is around 11-15 [14] and moisture content of 82-86\% [18]. Because of its high biodegradability and suitable $\mathrm{C} / \mathrm{N}$ ratio, OFMSW and food waste are potential co-substrates for anaerobic digestion. Fruit and vegetable waste, on the other hand, is a source-selected food waste consisting of only waste fruits and vegetables.

Table 2 shows the summary of studies utilizing OFMSW, FW or FVW as co-substrates for the anaerobic co-digestion of wastewater sludge. Cabbai, et al. [19] demonstrated an improvement of $16 \%$ and $48 \%$ in methane yield when co-digesting sewage sludge with FVW and FW in a volatile solids (VS) ratio of 1:0.23 and 1:2.09, respectively. However, the VS removal reduced by $25-40 \%$. Dai, et al. [14] showed an increase in methane yield from $25 \%$ to $67 \%$, and VS removal from $51 \%$ to $70 \%$, when the VS ratio of dewatered sludge and FW decreased from 2.4:1 to 0.4:1. These two studies indicated that a higher portion of the FW/FVW co-substrate brought about enhancement in methane yield compared to mono-digestion of wastewater sludge alone. This meets expectations, because FW contains higher biodegradable substrates for anaerobic digestion compared to sewage sludge, which is quite refractory to hydrolysis [20]. The limitation of using FW as a co-substrate is in the monitoring of the $\mathrm{Na}^{+}$and free-ammonia nitrogen (FAN) contents in the substrate, which needs to be less than $4 \mathrm{~g} \mathrm{~L}^{-1}$ for $\mathrm{Na}^{+}$[14] and $600 \mathrm{mg} / \mathrm{L}$ for FAN [21] to avoid system instability. Excess $\mathrm{Na}^{+}$could interfere with the metabolic process of the microbial activity [22], and excess FAN could lead to volatile fatty acid (VFA) accumulations [21].

Co-digesting wastewater sludge with OFMSW under mesophilic conditions was shown to achieve a methane yield enhancement of $59 \%$ and $89 \%$ in Silvestre, et al. [23] and Cavinato, et al. [24], 
respectively. The methane yield enhancement reached $233 \%$ when the co-digestion occurred under thermophilic conditions [24].

Their results contradict Al bkoor Alrawashdeh, et al. [25] who showed a 44\% reduction of methane yield when the sewage sludge was co-digested with OFMSW. The same study [25] showed that anaerobic digestion of waste untreated sludge alone gave the highest methane yield and VS removal compared to treating waste activated sludge or co-digestion with OFMSW. Despite similar VS and C/N ratios of the wastewater sludge and OFMSW, the differences in the methane yield enhancement and VS removal could be due to the heterogeneous OFMSW sample used in the experiments. In Silvestre, et al. [23] and Cavinato, et al. [24], the OFMSW came from a municipal solid waste facility, whereas in Al bkoor Alrawashdeh, et al. [25], the OFMSW originated from pre-selected household waste. Nevertheless, co-digestion with OFMSW generally aids in methane yield, as the higher $\mathrm{C} / \mathrm{N}$ ratio, VS and COD concentration of OFMSW (in the ranges of 17-36, 20-30\%, and $207-641 \mathrm{~g} / \mathrm{kg}$, respectively) could counterbalance the organic matter and nutrient deficiencies in sewage sludge during anaerobic co-digestion, thus improving the metabolic activity of the biomass, and, as a consequence, the enhancement in methane yield [26-28]. However, in order to incorporate OFMSW as a co-substrate for sewage sludge anaerobic co-digestion, it is strongly recommended that the impurities in the OFMSW be removed prior to the anaerobic co-digestion process to avoid hydrodynamic problems, and blockage of the pump system [28]. 
Table 2. Summary of studies utilizing FW, FVW or OFMSW as co-substrate in anaerobic co-digestion of wastewater sludge.

\begin{tabular}{|c|c|c|c|c|c|c|c|c|c|c|c|c|c|c|}
\hline & \multirow{2}{*}{$\begin{array}{l}\text { Primary } \\
\text { Substrate }\end{array}$} & \multirow{2}{*}{ Co-Substrate ${ }^{1}$} & \multirow{2}{*}{$\begin{array}{l}\text { Mixing } \\
\text { Ratio }^{2}\end{array}$} & \multirow{2}{*}{$\begin{array}{c}\text { Mode }^{3} \\
\text { (Volume) }\end{array}$} & \multirow{2}{*}{$\mathrm{T}^{4}$} & \multirow{2}{*}{ HRT (d) } & \multirow{2}{*}{$\begin{array}{c}\text { OLR (gVS } \\
\left.\mathbf{L}^{-1} \mathbf{d}^{-1}\right)\end{array}$} & \multicolumn{3}{|c|}{ VS Removal (\%) } & \multicolumn{3}{|c|}{ Methane Yield ( $\left.\mathrm{L} \mathrm{CH}_{4} \mathrm{~g}^{-1} \mathrm{VS}_{\text {added }}\right)$} & \multirow{2}{*}{ Ref. } \\
\hline & & & & & & & & Mono & Co & Improved \% & Mono & Co & Improved (\%) & \\
\hline 1 & Sewage sludge & FW & $60: 40 \mathrm{VS}$ & $\mathrm{C}(4 \mathrm{~L})$ & $\mathrm{M}$ & 8 & 3.5 & - & 42 & - & - & 0.18 & - & [29] \\
\hline \multirow{3}{*}{2} & \multirow{3}{*}{$\begin{array}{l}\text { Dewatered } \\
\text { sludge }\end{array}$} & \multirow{3}{*}{ FW } & 2.4:1 VS & \multirow{3}{*}{$C(6 \mathrm{~L})$} & \multirow{3}{*}{ M } & \multirow{3}{*}{30} & \multirow{3}{*}{$4-6$} & \multirow{3}{*}{38} & $\begin{array}{l}45 \\
51\end{array}$ & $\begin{array}{l}- \\
34\end{array}$ & - & $\begin{array}{l}0.20 \\
0.30\end{array}$ & $\begin{array}{l}- \\
25\end{array}$ & [29] \\
\hline & & & $0.9: 1 \mathrm{VS}$ & & & & & & 62 & 63 & 0.24 & 0.35 & 46 & \multirow[t]{2}{*}{ [14] } \\
\hline & & & $0.4: 1 \mathrm{VS}$ & & & & & & 70 & 84 & & 0.40 & 67 & \\
\hline 3 & Sewage sludge & $\mathrm{FVW}+\mathrm{FW}$ & 1:0.23 VS & $\mathrm{B}(1.2 \mathrm{~L})$ & M & 17 & - & 50 & 30 & -40 & 0.25 & 0.29 & 18 & [19] \\
\hline 4 & Sewage sludge & FVW & $100: 20 \mathrm{~V}$ & $C(100 \mathrm{~L})$ & M & $10-14$ & 2.1 & 22 & 24 & 9 & - & 0.38 & 47 & [30] \\
\hline \multirow{2}{*}{5} & Waste activated & & $50: 50 \mathrm{~V}$ & & M & 23.5 & 1.6 & & - & - & & 0.17 & 89 & \\
\hline & sludge & OFMSW & & $\mathrm{C}(380 \mathrm{~L})$ & $\mathrm{T}$ & 22.3 & 1.66 & & - & - & 0.09 & 0.30 & 233 & [24] \\
\hline 6 & Sewage sludge & OFMSW & 46:54 VS & $C(5.5 \mathrm{~L})$ & $\mathrm{M}$ & 20 & 1.9 & 36 & 70 & 94 & 0.22 & 0.35 & 59 & [28] \\
\hline 7 & Waste activated & OFMSW & $70: 30 \mathrm{~W}$ & $\mathrm{~B}(0.2 \mathrm{~L})$ & M & 100 & - & 65 & 58 & -11 & 0.25 & 0.22 & -12 & [25] \\
\hline & $\begin{array}{c}\text { sludge } \\
\text { Waste untreated }\end{array}$ & & $50: 50 \mathrm{~W}$ & & & & & & 58 & $\begin{array}{c}-11 \\
-8\end{array}$ & & 0.14 & -44 & \\
\hline 8 & $\begin{array}{l}\text { Waste untreated } \\
\text { sludge }\end{array}$ & OFMSW & $\begin{array}{l}70: 30 \mathrm{~W} \\
50: 50 \mathrm{~W}\end{array}$ & $\mathrm{~B}(0.2 \mathrm{~L})$ & $\mathrm{M}$ & 100 & - & 72 & $\begin{array}{l}66 \\
60\end{array}$ & $\begin{array}{c}-8 \\
-17\end{array}$ & 0.44 & $\begin{array}{l}0.29 \\
0.28\end{array}$ & $\begin{array}{l}-34 \\
-36\end{array}$ & [25] \\
\hline
\end{tabular}

${ }^{1}$ Co-substrate: FW, food waste; FVW, Fruit and vegetable waste; OFMSW, the organic fraction of municipal solid waste. ${ }^{2}$ Mixing ratio: V, by volume, VS, by volatile solids; W, by weight.

${ }^{3}$ Mode: $\mathrm{B}$, batch; $\mathrm{C}$, continuous. ${ }^{4} \mathrm{~T}$, Temperature: $\mathrm{M}$, mesophilic $\left(28-38^{\circ} \mathrm{C}\right)$; $\mathrm{T}$, thermophilic $\left(40-56{ }^{\circ} \mathrm{C}\right)$. 


\subsection{Crude Glycerol}

Crude glycerol, the main byproduct from biodiesel production, is a high-strength organic matter with an average COD of 1,200,000 mg/L and BOD of 97,080 mg/L [15]. It consists of glycerol, alcohol, salts, water, free fatty acids, heavy metals, methyl esters, and unreacted mono-, di-, and tri-glycerides [31,32]. The transesterification process produces biodiesel and crude glycerol at a volumetric ratio of 10:1 [33]. In 2011, with a total of 5.1 million tonnes of glycerol produced, only $40 \%$ were used, with the remaining 3 million tonnes a surplus. It is estimated that the global production of glycerol will reach 7.66 million tonnes in 2020 [34]. Therefore, glycerol management and its associated waste or value-added technologies play an important role.

The use of crude glycerol is limited because of the impurities, which affect its physical, chemical and biological properties [35]. There are currently two consumer markets for glycerol, the first being the already-existing market with the demand for high-purity glycerol, and the second being the use of lower-purity crude glycerol from biodiesel production. Due to limited market demand of the latter, biodiesel-producing industries are treating crude glycerol as industrial waste [35]. There are, however, some other industries not engaging in biodiesel production who are looking for alternative routes for crude glycerol as a raw material in other products [36].

One of the uses of crude glycerol is as a co-substrate for anaerobic digestion of low-strength wastes. Crude glycerol is difficult to treat biologically, due to its low nitrogen content and extreme $\mathrm{pH}$; however, due to its high carbon content and anaerobic biodegradability, it can be used as a co-substrate in the anaerobic digestion of low-strength wastes/wastewater, such as sewage sludge. The high alkalinity level of crude glycerol with a $\mathrm{pH}$ of 10.3 [37], can also act as a buffer for acidic waste.

Table 3 shows the studies using crude glycerol as the co-substrate in anaerobic co-digestion of wastewater sludge. When $1 \mathrm{vol} \%$ of crude glycerol was added to the anaerobic co-digestion of sewage sludge, the methane yield was increased by $115 \%$ in Fountoulakis, et al. [38], and $176 \%$ in Rivero, et al. [39], resulting in 0.56 and $2.1 \mathrm{~L} \mathrm{CH}_{4} \mathrm{~g}^{-1} \mathrm{VS}_{\text {added, }}$ respectively. The high methane yield in the latter was due to the use of optimized two-stage anaerobic digestion processes (acidogenic and methanogenic) and chemically pre-treated sewage sludge [39]. Despite the decrease in VS removal, dos Santos Ferreira, et al. [40] showed that the optimum crude glycerol addition was $0.5 \mathrm{vol} \%$ to achieve $73 \%$ enhancement in methane yield. The pilot-scale study by Razaviarani, et al. [41] showed that the optimum organic loading rate should be around $1.04 \mathrm{~g} \mathrm{VS} \mathrm{L}^{-1} \mathrm{~d}^{-1}$, corresponding to $1.1 \mathrm{vol} \%$ of glycerol addition to avoid process instability. Most of the studies were limited to using $1 \mathrm{vol} \%$ of crude glycerol as the co-substrate, as a higher dosage would result in reduction in alkalinity and thus, VFA accumulation and methanogen inhibition [41]. 
Table 3. Summary of studies using crude glycerol as a co-substrate in anaerobic co-digestion of wastewater sludge.

\begin{tabular}{|c|c|c|c|c|c|c|c|c|c|c|c|c|c|c|}
\hline & \multirow{2}{*}{$\begin{array}{l}\text { Primary } \\
\text { Substrate }\end{array}$} & \multirow{2}{*}{$\begin{array}{c}\text { Co- } \\
\text { Substrate }\end{array}$} & \multirow{2}{*}{$\begin{array}{l}\text { Mixing } \\
\text { Ratio }^{1}\end{array}$} & \multirow{2}{*}{$\begin{array}{l}\text { Mode }^{2} \\
\text { (Volume) }\end{array}$} & \multirow{2}{*}{$T^{3}$} & \multirow{2}{*}{ HRT (d) } & \multirow{2}{*}{$\begin{array}{c}\text { OLR (g VS } \\
\left.\mathbf{L}^{-1} \mathbf{d}^{-1}\right)\end{array}$} & \multicolumn{3}{|c|}{ VS Removal (\%) } & \multicolumn{3}{|c|}{ Methane Yield ( $\left.\mathrm{L} \mathrm{CH}_{4} \mathrm{~g}^{-1} \mathrm{VS}_{\text {added }}\right)$} & \multirow{2}{*}{ Ref. } \\
\hline & & & & & & & & Mono & Co & Improved \% & Mono & Co & Improved (\%) & \\
\hline 1 & Sewage sludge & Crude glycerol & 99:1 V & $C(3 \mathrm{~L})$ & M & $23-25$ & - & -79 & -32 & 60 & $0.26^{4}$ & $0.56^{4}$ & 115 & [38] \\
\hline \multirow[t]{2}{*}{2} & Sewage sludge & Crude glycerol & 98.9:1.1 V & SC (1200 L) & M & 20 & 1.04 & 42 & 52 & 24 & 0.62 & 0.87 & 40 & [41] \\
\hline & & & & & & 13 & 1.94 & & & & & 0.92 & 21 & \\
\hline \multirow[t]{2}{*}{3} & $\begin{array}{c}\text { Pre-treated } \\
\text { sewage sludge }\end{array}$ & Crude glycerol & $99: 1 \mathrm{~V}$ & SC (9 L) & M & $\begin{array}{c}11 \\
9\end{array}$ & $\begin{array}{l}2.11 \\
2.26\end{array}$ & - & $88-92$ & - & 0.76 & $\begin{array}{l}0.88 \\
0.98\end{array}$ & $\begin{array}{l}16 \\
29\end{array}$ & [39] \\
\hline & & & & & & 9 & 1.00 & & & & & 2.10 & 176 & \\
\hline 4 & Primary sludge & Crude glycerol & $124: 2-6 \mathrm{~W}$ & $C(4 \mathrm{~L})$ & M & 32 & $1.25-1.9$ & - & - & - & 0.35 & $0.55-0.75$ & $57-114$ & [42] \\
\hline 5 & Sewage sludge & Crude glycerol & $\begin{array}{c}99.5: 0.5 \mathrm{~W} \\
98: 2 \mathrm{~W}\end{array}$ & $\mathrm{C}(0.85 \mathrm{~L})$ & M & 17 & $1.81-3.68$ & $\begin{array}{l}53 \\
55\end{array}$ & $\begin{array}{l}62 \\
75\end{array}$ & $\begin{array}{l}17 \\
36\end{array}$ & $\begin{array}{l}0.40 \\
0.38\end{array}$ & $\begin{array}{l}0.36 \\
0.34\end{array}$ & $\begin{array}{l}-10 \\
-11\end{array}$ & [43] \\
\hline \multirow[t]{2}{*}{6} & Sewage sludge & Crude glycerol & $98.8: 1.2 \mathrm{~V}$ & C (5.5 L) & $\mathrm{M}$ & 20 & 1.2 & 36 & $\begin{array}{l}15 \\
57\end{array}$ & $\begin{array}{l}36 \\
58\end{array}$ & $\begin{array}{l}0.38 \\
0.22\end{array}$ & $\begin{array}{l}0.34 \\
0.29\end{array}$ & $\begin{array}{c}-11 \\
31\end{array}$ & [23] \\
\hline & & & 99:1 V & & & & & & 8 & -75 & & 0.010 & -78 & \\
\hline \multirow{3}{*}{7} & Sewage sludge & Crude glycerol & 99.7:0.3 V & $\mathrm{B}(0.05 \mathrm{~L})$ & $M$ & $15-30$ & - & 325 & 21 & -35 & 0045 & 0.062 & 38 & {$[40]$} \\
\hline & & & 99.5:0.5 V & $\mathrm{D}(0.00 \mathrm{~L})$ & $1 \mathrm{VI}$ & & - & & 19 & -42 & 0.075 & 0.078 & 73 & {$[40]$} \\
\hline & & & 99.3:0.7 V & & & & & & 16 & -51 & & 0.064 & 42 & \\
\hline
\end{tabular}

${ }^{1}$ Mixing ratio: V, by volume, VS, by volatile solids; W, by weight. ${ }^{2}$ Mode: $\mathrm{B}$, batch; C, continuous; $\mathrm{SC}$, semi-continuous. ${ }^{3} \mathrm{~T}$, Temperature: $\mathrm{M}$, mesophilic $\left(28-38{ }^{\circ} \mathrm{C}\right) ; \mathrm{T}$, thermophilic $\left(40-56{ }^{\circ} \mathrm{C}\right) .{ }^{4}$ Taking VS of crude glycerol as $800 \mathrm{~g} / \mathrm{L}$ (averaged from $[37,42,43]$ ) unless specified. 
A proper amount of crude glycerol added (1-1.2 vol\% [23]) may aid in the specific biomass activity, as the degradation of crude glycerol results in the formation of more acetate, hydrogen, and propionate and, as a consequence, enhance the methane yield [23].

\subsection{Agricultural Wastes}

Agricultural waste (also called agro-waste) includes animal waste, food processing waste, crop waste, and hazardous and toxic agricultural waste [44]. Rice husks, coconut husks and shells, wheat straw, sugarcane fiber, and groundnut shells are examples of the most common agricultural plant residues. Animal waste includes cattle, pig and chicken manures. The major characteristics of manures are often associated with high nitrogen content and the presence of easily-formed sulfur, ammonia, and hydrogen sulfide gasses. Hence, mono-digestion of manures bring about excessive nutrients and organic matter in the digester, thus inhibiting the production of methane. However, due to its high nutrient content, it is a potential co-substrate for the main substrate with low nutrient content such as sewage sludge. Although most agricultural residues or energy crops are lignocellulosic biomasses, with carefully designed operating conditions, the anaerobic digestion process of these biomasses may have the ability to promote methane from hemicellulose, which destabilizes the recalcitrant biomass structure, allowing for improved solubilization of cellulose by commercial enzymes in the downstream processes [45,46]. Mono-digestions of other agricultural waste, especially farm waste, have been demonstrated to be successful $[6,47]$. Therefore, due to its large availability and variety, agricultural waste could be a potential co-substrate for anaerobic co-digestion of wastewater sludge.

Table 4 summarizes the studies using agricultural waste as co-substrates for wastewater sludge anaerobic co-digestion. Sugar beet pulp, olive and grape pomaces, paper pulp reject, cheese whey, sheep manure, and brewery spent grain were utilized. The use of $50 \mathrm{vol} \%$ of paper pulp reject was able to boost up to $131 \%$ of the methane yield compared to sewage sludge-anaerobic digestion alone, due to its mostly cellulose nature in powder form, which resulted in faster hydrolysis [48]. The use of $5 \mathrm{vol} \%$ and $10 \mathrm{vol} \%$ cheese whey were also shown to improve methane yield by $44 \%$ [49] and $121 \%$ [50], respectively. This enhancement is likely due to the improved $\mathrm{C} / \mathrm{N}$ ratio of the feedstock mixture [51]. Maragkaki, et al. [50] compared the use of different co-substrates with a ratio of $5-10 \mathrm{vol} \%$ using grape residue, sheep manure, cheese whey, with crude glycerol and food waste for sewage sludge-anaerobic co-digestion. They found that crude glycerol was the best co-substrate, followed by food waste, which was comparable with cheese whey, and lastly grape residue. Sheep manure was found to yield no improvement, and deteriorated methane yield and VS removal [50]. Co-digesting sewage sludge with acid cheese whey was also found to have negligible improvement. However, with both acid cheese whey and brewery spent grain at a sewage sludge: acid cheese whey ratio of 89: 11 , and an acid cheese whey: brewery spent grain ratio of $10 \mathrm{~g}: 1 \mathrm{~L}$, a methane yield enhancement of $56 \%$ was achieved [52]. Thus, selection of a suitable co-substrate and optimization of the operating conditions according to the properties of the main substrate remains to be the major challenge before these co-substrates can be utilized in a WWTP. 
Table 4. Summary of studies using agricultural wastes as co-substrate in anaerobic co-digestion of wastewater sludge.

\begin{tabular}{|c|c|c|c|c|c|c|c|c|c|c|c|c|c|c|}
\hline & \multirow{2}{*}{$\begin{array}{l}\text { Primary } \\
\text { Substrate }\end{array}$} & \multirow{2}{*}{ Co-Substrate } & \multirow{2}{*}{$\begin{array}{l}\text { Mixing } \\
\text { Ratio }^{1}\end{array}$} & \multirow{2}{*}{$\begin{array}{l}\text { Mode }^{2} \\
\text { (Volume) }\end{array}$} & \multirow{2}{*}{$T^{3}$} & \multirow{2}{*}{ HRT (d) } & \multirow{2}{*}{$\begin{array}{c}\text { OLR (g VS } \\
\left.\mathbf{L}^{-1} \mathbf{d}^{-1}\right)\end{array}$} & \multicolumn{3}{|c|}{ VS Removal (\%) } & \multicolumn{3}{|c|}{ Methane Yield ( $\left.\mathrm{L} \mathrm{CH}_{4} \mathrm{~g}^{-1} \mathrm{VS}_{\text {added }}\right)$} & \multirow{2}{*}{ Ref. } \\
\hline & & & & & & & & Mono & Co & Improved \% & Mono & Co & Improved \% & \\
\hline \multirow{5}{*}{1} & \multirow{5}{*}{ Sewage sludge } & \multirow{5}{*}{ Sugar beet pulp } & \multirow{5}{*}{-} & \multirow{5}{*}{$\mathrm{SC}(5 \mathrm{~L})$} & \multirow{5}{*}{ M } & 30 & 1.1 & & & & & 0.17 & \multirow{5}{*}{-} & \multirow{5}{*}{ [53] } \\
\hline & & & & & & 20 & 1.2 & & & & & 0.10 & & \\
\hline & & & & & & 15 & 1.8 & - & - & - & - & 0.16 & & \\
\hline & & & & & & 10 & 2.1 & & & & & 0.34 & & \\
\hline & & & & & & 6 & 5 & & & & & 0.06 & & \\
\hline 2 & $\begin{array}{c}\text { Waste activated } \\
\text { sludge }\end{array}$ & Olive pomace & $50: 50 \mathrm{~W}$ & $\mathrm{~B}(1.6 \mathrm{~L})$ & M & 30 & - & 40 & 45 & 12.5 & 0.16 & 0.21 & 31 & [54] \\
\hline 3 & Sewage sludge & \multirow{2}{*}{$\begin{array}{l}\text { Cheese whey } \\
\text { Paper pulp } \\
\text { reject }\end{array}$} & $95: 5 \mathrm{~V}$ & B (180 L) & M & 24 & 1.1 & 19 & 25 & 32 & 0.25 & 0.36 & 44 & [49] \\
\hline 4 & Primary sludge & & $50: 50 \mathrm{~V}$ & B $(0.75 \mathrm{~L})$ & M & 13 & - & - & - & - & 0.16 & 0.37 & 131 & [48] \\
\hline 5 & $\begin{array}{l}\text { Waste activated } \\
\text { sludge }\end{array}$ & $\begin{array}{l}\text { Olive and grape } \\
\text { pomaces }\end{array}$ & - & B (1.6 L) & M & 30 & - & 35 & $52-55$ & $49-57$ & 0.06 & 0.07 & 17 & [51] \\
\hline \multirow{3}{*}{6} & \multirow{3}{*}{ Sewage sludge } & Grape residue & $95: 5 \mathrm{~V}$ & $C(3 \mathrm{~L})$ & \multirow{3}{*}{ M } & \multirow{3}{*}{24} & 1 & 46 & 41 & -11 & 0.17 & 0.22 & 29 & \multirow{3}{*}{ [50] } \\
\hline & & Sheep manure & $95: 5 \mathrm{~V}$ & $C(3 \mathrm{~L})$ & & & 1.3 & 38 & 25 & -34 & 0.17 & 0.14 & -21 & \\
\hline & & Cheese whey & $90: 10 \mathrm{~V}$ & $C(1 \mathrm{~L})$ & & & 0.8 & 43 & 27 & -37 & 0.14 & 0.31 & 121 & \\
\hline \multirow{3}{*}{7} & \multirow{3}{*}{ Sewage sludge } & Acid cheese & $90: 10 \mathrm{~V} *$ & \multirow{3}{*}{ SC (40 L) } & \multirow{3}{*}{ M } & 20 & 1.75 & 34 & 40 & 18 & 0.27 & 0.26 & -4 & \multirow{3}{*}{ [52] } \\
\hline & & whey + & $91: 9 \mathrm{~V} *$ & & & 18 & 2.9 & 34 & 42 & 24 & 0.27 & 0.27 & 0 & \\
\hline & & $\begin{array}{l}\text { brewery spent } \\
\text { grain }\end{array}$ & $89: 11 \mathrm{~V} *$ & & & 16.7 & 2.35 & 46 & 46 & 0 & 0.18 & 0.28 & 56 & \\
\hline
\end{tabular}

${ }^{1}$ Mixing ratio: V, by volume, VS, by volatile solids; W, by weight; * Sewage sludge: Acid cheese whey: $90: 10 \mathrm{~V}$ at a brewery spent grain mass: feedstock volume ratio of 10 g: $1 \mathrm{~L} .{ }^{2}$ Mode: $\mathrm{B}$, batch; C, continuous, $\mathrm{SC}$, semi-continuous. ${ }^{3} \mathrm{~T}$, Temperature: $\mathrm{M}$, mesophilic $\left(28\right.$ to $\left.38^{\circ} \mathrm{C}\right)$; $\mathrm{T}$, thermophilic $\left(40\right.$ to $\left.56^{\circ} \mathrm{C}\right)$. 


\subsection{Fat, Oil and Grease (FOG)}

Fat, oil and grease is a term commonly used to describe lipid-rich waste material primarily from edible oil producers, food processing industries, slaughterhouses, and food wastes [55]. It can be grouped as grease trap, waste cooking oil (yellow grease), and interceptor wastes (brown grease) consisting of yellow grease, water and food solids [56]. Since FOG has the tendency to accumulate on pipe walls through a physical or chemical aggregation process, the direct discharge of FOG into municipal wastewater collection systems is illegal in many countries, because it would cost the municipalities a large amount of money in cleaning and maintenance [57]. Therefore, the current best treatment method for waste FOG is separate collection for recycling (to be used for biodiesel), or proper disposal.

FOG constituents include biodegradable lipids which present as neutral fats (i.e., triglycerides), and saturated or unsaturated long chain fatty acids (LCFAs) [58,59]. Generally, lipids in FOG are first hydrolyzed to glycerol and LCFAs in the anaerobic digestion process. Subsequently, LCFAs can be degraded anaerobically to acetate via $\beta$-oxidation pathways to short-chain fatty acids, acetate, hydrogen, and methane; whereas glycerol is degraded to acetate. These acetates are then anaerobically degraded to methane $[57,60]$. Since the degradable fraction of lipids is higher than the mainstream carbohydrate and proteins present in sewage sludge, anaerobic digestion of FOG theoretically could generate higher biogas production [61]. Although FOG is regarded as an energy, value-added material, and recognized as an advantage for incineration and biodiesel generation processes, anaerobic co-digestion with FOG is considered a proper treatment method, because it requires insignificant pre-treatment, and produces higher amounts of biogas [62,63].

Studies utilizing FOG as co-substrate in wastewater sludge anaerobic co-digestion are summarized in Table 5. Co-digestion studies with FOG are relatively more complete and established than other co-substrates discussed earlier. Results show a notably-improved methane yield ranging from 13 to $198 \%$. Most of these studies showed that about 50:50\% of sewage sludge and FOG to grease trap waste on a VS basis offered comparatively higher methane yield, achieving close to $0.50 \mathrm{~L} \mathrm{CH}_{4} / \mathrm{g}$ $\mathrm{VS}_{\text {added }}[64,65]$. Higher than that (e.g., more than $60 \mathrm{VS} \%$ of FOG/grease trap waste) would result in biomass aggregation and thus, create a mass transfer limitation due to LCFA accumulation on and in the biomass aggregates $[65,66]$. The high LCFA content in the FOG/grease trap waste due to degradation of lipid-rich materials, is a known inhibitor of methanogenic bacteria, which would usually cause a lag between LCFA degradation and methane production [67], and lead to operational problems such as clogging and scum formation. Co-digesting with sewage sludge helps in diluting the inhibitive LCFA $[4,64]$. Due to the carbohydrate and/or protein content in the sewage sludge, such inhibition could be alleviated [68].

\section{Factors Influencing Co-Digestion Performance}

Several factors affect the functioning of anaerobic digesters and feasibility of co-digestion where sufficient control is needed to prevent reactor failure. A few of the major influences that greatly affect digester performances in co-digestion are mixing, co-substrate mixing ratio and nutrient balance, operating temperature, organic loading rates (OLR), and hydraulic retention time (HRT) in the digester. Based on the results as seen in Tables 2-5, these factors are further analyzed, reviewed, and discussed in the following sections to gain deeper insight and consideration for future research. Summarized optimum operating conditions are also presented. 
Table 5. Summary of studies utilizing FOG as a co-substrate in wastewater sludge co-digestion.

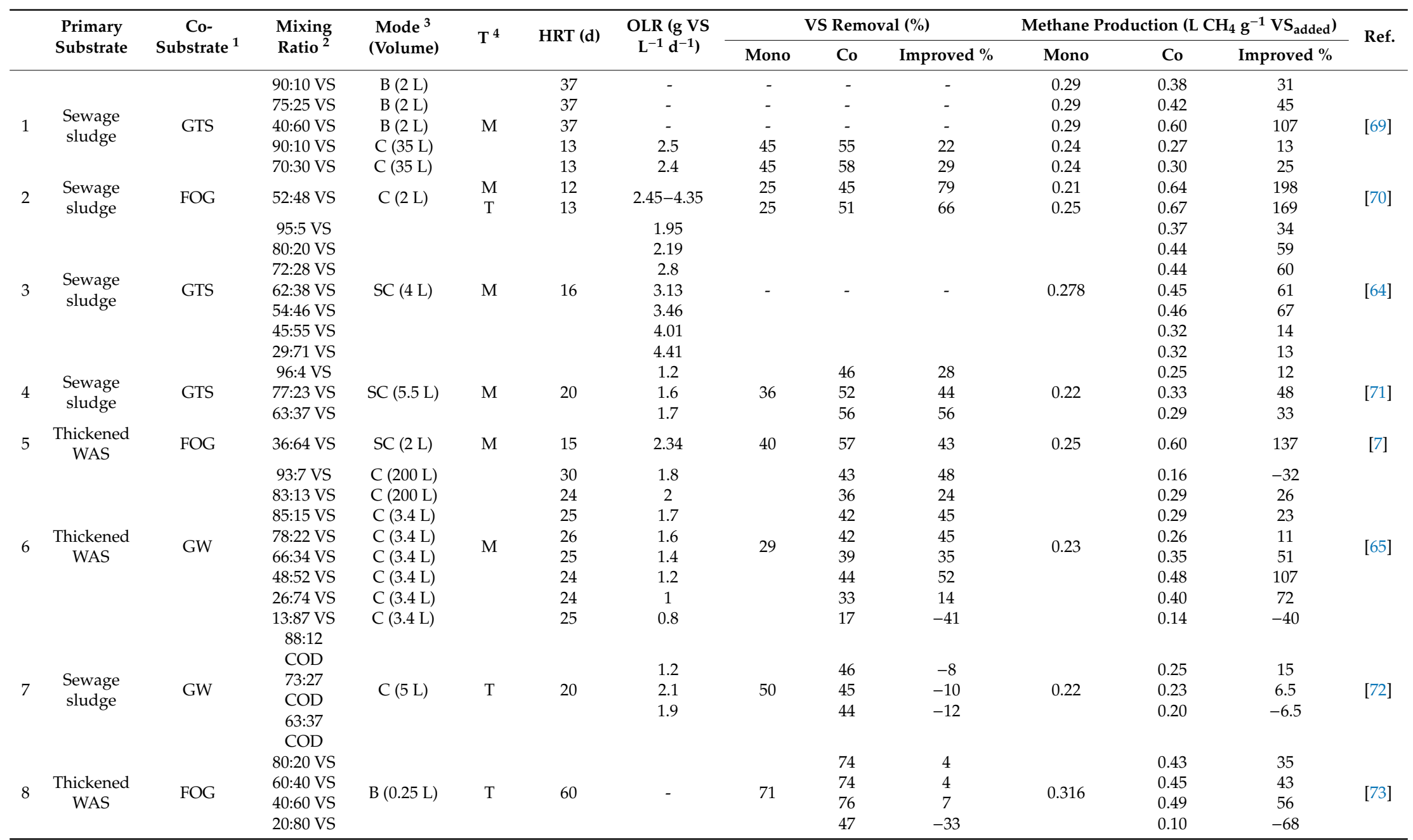

1 Co-substrate: GTS, grease trap sludge; FOG, fat oil and grease; GW, grease waste. ${ }^{2}$ Mixing ratio: VS, by volatile solids; COD, by COD. ${ }^{3}$ Mode: C, continuous; B, batch; SC, semi-continuous. ${ }^{4} \mathrm{~T}$, temperature: $\mathrm{M}$, mesophilic $\left(28\right.$ to $\left.38^{\circ} \mathrm{C}\right) ; \mathrm{T}$, thermophilic $\left(40\right.$ to $\left.56^{\circ} \mathrm{C}\right)$. 


\subsection{Mixing}

Mixing provides a good contact between microbes and substrates, improves the ability of bacterial population to obtain nutrients, and promotes homogenous feed to the digester. Mixing also reduces the forming of inhibitory intermediates such as scum, and stabilizes digestion conditions by preventing the development of temperature gradients [74]. Pockets of material may weaken the overall rate of the process at different stages of $\mathrm{pH}$ and temperature when mixing is inadequate. Mixing can be done through mechanical mixing, biogas recirculation, or through slurry recirculation [75]. Mixing also improves gas production compared to unmixed digesters [76]. This has been proven in the study performed by Rizk, et al. [77], in which ACD of wastewater treatment plant sludge and the OFMSW with no mixing system in a $70 \mathrm{~L}$ reactor under mesophilic conditions showed that most biogas and methane generated only at the first month of operation. This suggests that a mixing system needs to be installed in the digester, particularly in co-digestion, to ensure a sufficient homogeneity besides improving digester performance.

The effects of varying mechanical mixing conditions on co-digestion operations studied by Stroot, et al. [78] affirmed that a low mixing state $(80 \mathrm{rpm})$ is more effective than a high mixing speed (200 rpm). This is because excessive mixing can interrupt the microorganisms in their ability to digest. This indicates that setting an optimum mixing speed is essential, as it could substantially affect the digestion and biogas production rates. However, Karim, et al. [76] mentioned that mixing during the start-up is not beneficial, because it lowers the digester $\mathrm{pH}$, resulting in performance instability, and leading to delays in the start-up period. Hence, $\mathrm{pH}$ should be considered to obtain a suitable condition in the digester during mixing for the best digester performance. Some studies have also affirmed that intermittent mixing, known as semi-continuous mixing, is better than continuous mixing. Unlike continuous mixing, which breaks the syntrophic relationship between acetogens and methanogens [79], semi-continuous mixing provides sufficient time for microbial growth, which then enhances the mass transfer from the liquid-to-gas phase, and ultimately increases the methane yield [80]. Apart from the common impeller driven mixing method to aid mass and heat transfer, some novel mixing innovations have also been developed, such as the Pneu-mechanical mixer [81] and biogas recirculation using a new ' $\mathrm{O}$ ' shaped diffuser design [79], which contributes to the synergistic effect of carbon dioxide acidification and, thus, reduces digester $\mathrm{pH}$, ammonia control and methane enrichment.

\subsection{Co-Substrate Mixing Ratio and Nutrient Balance}

The $\mathrm{C} / \mathrm{N}$ ratio represents the correlation between the amount of carbon and nitrogen present in organic matter. This ratio is the balance of food that a microbe needs to grow in order to perform digestion of organic matter. The optimum $\mathrm{C} / \mathrm{N}$ ratios in anaerobic digesters are usually between 20:1 and 30:1 [82]. A rapid utilization of nitrogen by the methanogens results in a lower gas production, and this is indicated with a high $\mathrm{C} / \mathrm{N}$ ratio. Conversely, a lower $\mathrm{C} / \mathrm{N}$ ratio causes the ammonia deposition and $\mathrm{pH}$ to surpass 8.5 , which is considerably toxic to methanogenic bacteria. Therefore, to achieve an ideal ratio of $\mathrm{C} / \mathrm{N}$ in the co-digestion, it is suggested to have a mixture of waste with a low and high $\mathrm{C} / \mathrm{N}$ ratio.

Various mixture ratios often substantially affect the outcomes, as the ratio reflects the nutrient balance in it. An ideal mixing ratio for OFMSW is recommended within $20-50 \mathrm{vol} \%$ to achieve optimum nutrient balance in the digester (Table 2). This recommendation has been verified by Heo, et al. [83], who conducted ACD of food wastes with sludge at a 50:50 ratio. The mixture of a high and low $\mathrm{C} / \mathrm{N}$ ratio resulted in an improved ratio from 6 to 16. Although the obtained $\mathrm{C} / \mathrm{N}$ ratio of 16 is considered below optimum, this improved ratio tended to have an overall better digestion performance in terms of effluent volatile solids concentration, buffer capacity, and methane production.

An optimum substrate mixing ratio for crude glycerol is relatively low at $0.5-1.2 \mathrm{vol} \%$, as shown in Table 3. This is due to a high $\mathrm{C} / \mathrm{N}$ ratio of crude glycerol at 68 , indicating that a rapid consumption of nitrogen by the methanogens leads to low biogas production if added in high concentration. To ensure stable operation, the addition of glycerol should not exceed $4 \%$ under mesophilic conditions, to avoid 
adding excess nitrogen, which will trigger the generation of high acetic acid, eventually causing a decrease in $\mathrm{pH}$. This would then cause the methanogens to consume for a longer period to adjust and overcome the $\mathrm{pH}$, hence reducing methane production.

The substrate mixing ratio for agricultural wastes, on the other hand, is suggested within $5-50 \mathrm{vol} \%$ based on Table 4 . The range appeared to be large as it is dependent on the selection of pairing substrates. Conversely, it is advised to keep the digestion ratio for FOG within 5-60 VS\% to avoid an overly low or high $\mathrm{C} / \mathrm{N}$ ratio based on Table 5 . This is because the $\mathrm{C} / \mathrm{N}$ ratio for FOG is variable depending on the type of FOG existing in either grease traps, waste cooking oil, or interceptor wastes forms. The $\mathrm{C} / \mathrm{N}$ ratio for FOG can be as low as 9 or as high as 15 . Hence, it is safe to start the ratio at approximately $50 \%$ for stable methane improvement without excessive or insufficient nutrients.

\subsection{Operating Temperature}

Co-digestion treatment under both mesophilic and thermophilic conditions are feasible depending on the substrates. Numerous researchers have highlighted the significant effects of temperature on the microbial community, process kinetics, and stability and methane yield. Lower temperatures during the process are known to decrease microbial growth, substrate utilization rates, and biogas production. Lower temperatures may also result in an exhaustion of cell energy, a leakage of intracellular substances or complete lysis $[84,85]$. Although higher temperatures allow a reduced volume of waste mass in small reactors, making it more effective in minimizing lipids, and could accommodate higher loading capacity, it also could result in lower biogas yield. This is due to the production of volatile gases such as ammonia, which suppress methanogenic activities [86]. Therefore, it is suggested that different temperature conditions are required to match with different substrates, due to the characteristics of each substrate.

A thermophilic condition is recommended as favorable for the OFMSW. This finding has been proven by Li, et al. [87] and Kim, et al. [29], who performed ACD of food waste OFMSW under a thermophilic condition, and observed a better performance than conventional the mesophilic process for methane production and digestion capability. Similarly, the study conducted by Lee, et al. [88] showed that a thermophilic condition is more favorable compared to mesophilic and hyperthermophilic. This may be the result of the slow adaptation of microorganism, which are likely to be degraded, and release nutrients under a hyperthermophilic condition, leading to the overall inhibition of methane production.

Likewise, a mesophilic condition is ideal for the ACD with crude glycerol. As the crude glycerol has a high alkaline level at $\mathrm{pH}$ averaging 10.3 , it is usually co-digested with acidic waste to form a neutral $\mathrm{pH}$. However, when the temperature increases, acetate is the first acid to increase. Subsequently, the more acetate formed, the more the main part of VFA concentration constrains methanogenic bacteria [89]. Various researchers, including Fountoulakis and Manios [90], Fountoulakis, et al. [38] and Rivero, et al. [39], have also demonstrated a significantly higher increase in methane under mesophilic with an average increase ranging from $115 \%$ to $176 \%$, as reflected in Table 3 .

As for co-digesting with agricultural waste (Table 4), most of the studies which can be found were operating under mesophilic conditions [6]. It was demonstrated in some studies that a thermophilic condition was beneficial for degradation of some agricultural plant residue waste such as maize [91], rice straw and risk husk [92]. However, a mesophilic condition is a better option for ACD with manures to overcome ammonia inhibition. According to Zeeman, et al. [93], ammonia increases with the increase of $\mathrm{pH}$ and temperature. Hence, the thermophilic condition will result in a higher concentration of free ammonia, which is regarded as an active component causing ammonia inhibition. This would result in higher VFA concentration, which negatively affects the activity of methanogenic bacteria and, hence, achieves a low methane yield.

On the other hand, ACD of FOG is more suitably treated under a mesophilic condition. A major concern of FOG is primarily the harmful effect of long-chain fatty acids on methanogenic bacteria, which coats the bacteria in a layer and constrains cell access to substrates, resulting in poor release of 
biogas [94-96]. Although the thermophilic condition allows the accessibility of lipids to microorganisms, and their lipolytic enzymes caused by the increased diffusion coefficients and lipid solubility in aqueous media, this has not been the case in recent studies. As evidenced in Table 5, Kabouris, et al. [70] showed that a mesophilic condition could achieve a greater improvement at $198 \%$ of methane yield compared to thermophilic at $169 \%$. These results indicate that a thermophilic condition may increase nutrient release, and thermophilic bacteria may be more sensitive to LCFA inhibition than mesophilic bacteria. In addition, a thermophilic operation does not always offer sufficiently higher volatile solids reduction to justify the cost associated with the increased energy for heating.

\subsection{Organic Loading Rate (OLR) and Hydraulic Retention Time (HRT)}

OLR, a crucial parameter, describes the amount of volatile solids to be fed into the digester each day. Volatile solids signify the amount of organic solids that can be digested, while the remaining solids are non-degradable. The optimum OLR and HRT often depend on the type of substrates fed into the digester, since the substrates determine the activity level of biodegradation that will occur in the digester. ACD with OFMSW or food waste is suitable for treatment at a low-range OLR $<2 \mathrm{gVS} \mathrm{L}^{-1} \mathrm{~d}^{-1}$ with HRT of 25 days (Table 2). This is due to the considerably high COD concentration of the OFMSW of food waste averaging 252,000 mg/L. Therefore, bacteria would need a longer time to degrade the high-strength OFMSW, and not overfeed at the same time, which could form tension in ACD. This recommendation has been verified by Babaee and Shayegan [97], who proposed that stable performance was achieved under an OLR of $1.4 \mathrm{~g}$ VS/L.day with a HRT of 25 days. This finding is also cohesive with the findings in Mata-Alvarez, et al. [98].

Similarly, it is advised to keep ACD with crude glycerol below an OLR $2 \mathrm{gVS} \mathrm{L}^{-1} \mathrm{~d}^{-1}$ for VS with similar HRT of 20-30 days as shown in Table 3. It is also important to add glycerin gradually to allow bacteria to acclimatize to gain better results at increasing an OLR. Unlike the OFMSW and crude glycerol, ACD of agricultural waste can accommodate a higher OLR of up to $2.35 \mathrm{gVS} \mathrm{L}^{-1} \mathrm{~d}^{-1}$ with a HRT of 17 days [52] (Table 4). This is due to the lower COD concentration averaging 131,000 mg/L [99,100] compared to crude glycerol. ACD with FOG, on the other hand, was found to be working effectively under a high OLR up to $4 \mathrm{gVS} \mathrm{L}^{-1} \mathrm{~d}^{-1}$ with a HRT of 16 days, as shown in Table 5. A higher OLR could increase the carbon source in the treatment. However, an OLR higher than recommended may cause damage to technical components such as mixers or pumps, or require earlier maintenance than scheduled. Therefore, a HRT of 20-30 days could provide satisfactory co-digestion and stable biogas production. This is to allow sufficient time for the introduction of digesting bacteria to break down organic matter and to generate methane.

\section{Summary and Challenges of ACD of Wastewater Sludge}

Table 6 summarizes the findings from the review of utilizing OFMSW/FW, CG, AW and FOG as the co-substrates for sewage sludge-anaerobic co-digestion. Note that the comparison shown uses the recommended or widely-used OLR and HRT of 1-2.5 $\mathrm{gVS} \mathrm{L}^{-1} \mathrm{~d}^{-1}$ and 15-30 days, respectively, as the criteria, which is the common operating condition of a WWTP. The mixing ratio, preferred temperature mode, VS removal efficiency, and methane yield for each co-substrate are summarized. The ease and effectiveness of integrating these co-substrates in the anaerobic co-digestion of sewage sludge are then rated with the challenges outlined for future reference. 
Table 6. Summary of reviews on co-substrates (at OLR $=1-2.5 \mathrm{gVS} \mathrm{L}^{-1} \mathrm{~d}^{-1}$ and $\mathrm{HRT}=15-30$ days).

\begin{tabular}{|c|c|c|c|c|c|c|}
\hline & & SS & OFMSW/FW & CG & AW & FOG \\
\hline 1 & Mixing ratio (\%) with respect to SS ${ }^{1}$ & 100 & $20-50 \mathrm{~V}$ & $0.5-1.2 \mathrm{~V}$ & $5-50 \mathrm{~V}$ & $5-50 \mathrm{VS}$ \\
\hline 2 & Preferred temperature mode ${ }^{2}$ & M & $\mathrm{T}$ & $\mathrm{M}$ & $\mathrm{M}$ & $\mathrm{M} / \mathrm{T}$ \\
\hline 3 & VS removal \% & $22-50$ & $24-70$ & $52-72$ & $25-55$ & $36-58$ \\
\hline 4 & Methane yield ( $\left.\mathrm{L} \mathrm{CH}_{4} \mathrm{~g}^{-1} \mathrm{VS}_{\text {added }}\right)$ & $0.22-0.25$ & $0.17-0.38$ & $0.29-0.65$ & $0.10-0.37$ & $0.16-0.50$ \\
\hline \multicolumn{7}{|c|}{ Evaluation of the effectiveness of implementing anaerobic SS-co-digestion with the co-substrate in a WWTP: } \\
\hline 5 & $\begin{array}{l}\text { Benefits and challenges } \\
{[6,23,39,49,55]}\end{array}$ & & $\begin{array}{l}\text { Highly abundant; } \\
\text { greatly helps divert } \\
\text { waste from landfills. } \\
\text { Impurity level affects } \\
\text { the operational } \\
\text { condition; not ideal } \\
\text { for WWTP design. } \\
\text { - Effective source } \\
\text { collection and } \\
\text { segregation system; } \\
\text { increases cost } \\
\text { of management. }\end{array}$ & $\begin{array}{ll}\text { - } & \text { Best co-substrate to } \\
\text { improve VS removal } \\
\text { and methane yield. } \\
\text { - } \quad \text { High anaerobic } \\
\text { bio-degradability; low } \\
\text { impact on digester } \\
\text { solids management. } \\
\text { - } \quad \text { impler feed } \\
\text { implementation and } \\
\text { better hydrodynamics; } \\
\text { lower } \\
\text { operational problems. } \\
\text { Not commonly } \\
\text { available; low } \\
\text { perception of } \\
\text { biodiesel companies. }\end{array}$ & 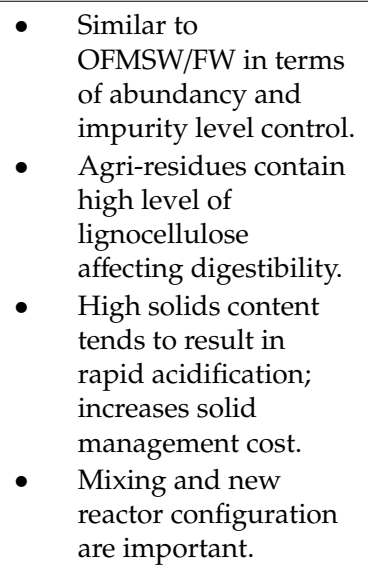 & $\begin{array}{l}\text { - } \quad \text { Most researched. } \\
\text { Transport limitation } \\
\text { due to LCFAs, scum } \\
\text { formation and sludge } \\
\text { flotation problems; } \\
\text { limited efficiency. } \\
\text { May be more } \\
\text { economical than ACD } \\
\text { in } \\
\text { biodiesel production } \\
\text { Pre-treatment of FOG } \\
\text { and properly } \\
\text { designed sludge bed } \\
\text { are important. }\end{array}$ \\
\hline 6 & Rating & & $\star \star$ & 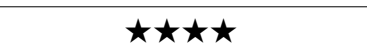 & $\star$ & $\star \star \star$ \\
\hline
\end{tabular}

${ }^{1}$ Mixing ratio (\%) with respect to sewage sludge: V, by volume; VS, by volatile solids. ${ }^{2}$ Preferred temperature mode: M, mesophilic; T, thermophilic. 
Based on the above analysis (Table 6), though the highly abundant OFMSW/FW and AW are able to improve VS removal and methane yield compared to SS mono-digestion alone, the costs associated with solids management, and a separate source collection and segregation system to alleviate the operational problems of the anaerobic digester would be increased [28]. And, while FOG is a potential co-substrate, it requires pre-treatment and a sludge bed operational condition design to avoid operational problems such as scum formation and biomass washout. A lifecycle assessment study by Tu [101] pointed out, however, that waste FOG in the processing of biodiesel is a more effective option compared to using it as an anaerobic co-substrate. Another approach known as dual-fuel can, nevertheless, be carried out to separate the higher-grade layer of FOG for biodiesel production and the lower-grade layer of FOG for anaerobic co-digestion [102,103]. Crude glycerol appears to be the best co-substrate candidate for SS anaerobic co-digestion, as it has high anaerobic biodegradability, which is able to significantly increase the OLR, while having minimal impact on the HRT [43]. Because it is in liquid form, crude glycerol requires a lower investment, as it requires simple feed implementation, and has a low impact on digestate solid management [39]. A typical anaerobic digester utilizes only $40-50 \%$ of the influent organic matter to convert to methane. Based on the outcome of this review, a recommendation is provided in Figure 1 that outlines a possible way of integrating anaerobic co-digestion using waste crude glycerol or lower-grade FOG into a WWTP to boost the methane yield, and thus offset the energy consumption.

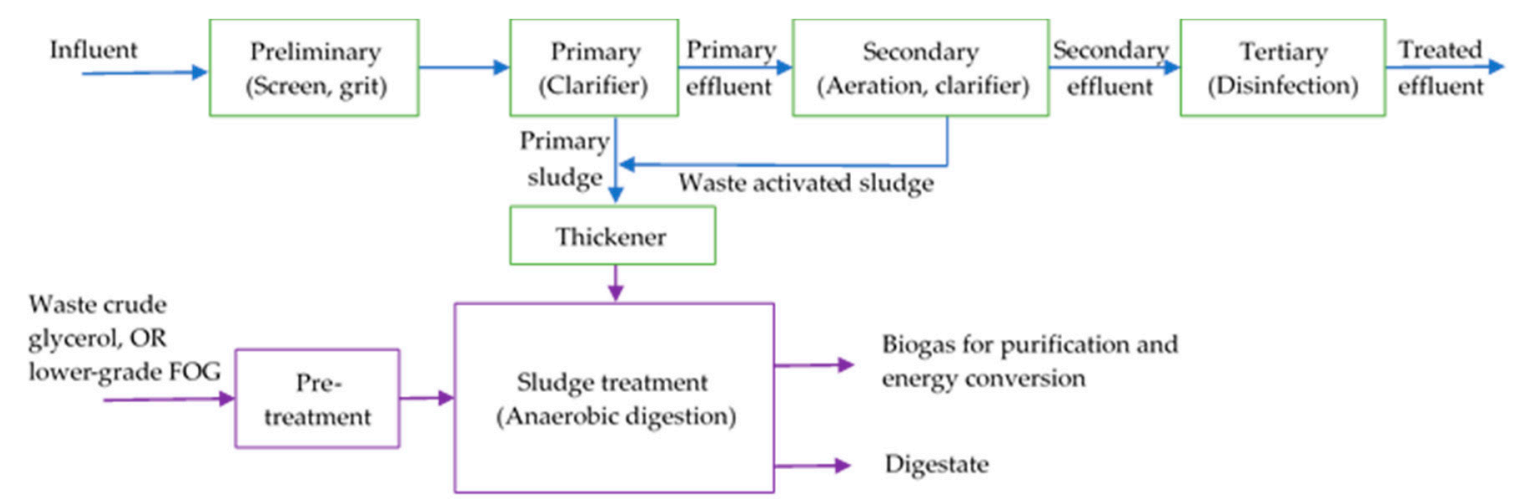

Figure 1. A suggested scheme for integrating anaerobic co-digestion of sewage sludge into a WWTP.

\section{Conclusions}

This paper summarizes the recent research on the ACD of wastewater sludge such as sewage sludge, waste activated sludge, and thickened waste activated sludge, with some potential co-substrates. The review shows that ACD of wastewater sludge involving co-substrates of OFMSW/FW, crude glycerol, agricultural waste, and FOG show potential in boosting biogas production and methane yield. ACD can also reduce costs from shared equipment, create easier handling of feedstock, and create a more stable process in general. The main challenges in ACD technology are process instability, which is mainly due to inappropriate substrate ratios, and operating conditions. Therefore, the anaerobic co-digestion system needs to be designed by considering the operating conditions such as a slow mixing system and a mixture of waste with low and high $\mathrm{C} / \mathrm{N}$ ratio at the right mixing ratio. It can be concluded that out of these four potential co-substrates, crude glycerol at a mixing ratio of $0.5-1.2 \mathrm{vol} \%$, and lower-grade FOG at 5-50 VS\% are the most feasible for integration into a WWTP, in terms of VS removal, methane yield improvement, and operational and management costs. Future research is required focusing on the optimization of the operating parameters, kinetic and thermodynamic modeling, cost analysis, and lifecycle assessment to further evaluate its scale-up feasibility. 
Author Contributions: Conceptualization and writing, W.L.C.; review and editing, S.C. and T.J.T.; supervision, Y.J.C. and M.F.C.; administration, G.-T.P.; funding acquisition, J.W.L. and J.K.C.

Funding: One of our authors, Jun Wei Lim, wishes to acknowledge the financial supports from the International Grant awarded by Universitas Muhammadiyah Purwokerto with grant number 015ME0-094 and Ministry of Education Malaysia under HICoE with grant number 015MA0-052.

Conflicts of Interest: The authors declare no conflicts of interest.

\section{References}

1. Chan, Y.J.; Chong, M.F.; Law, C.L. Performance and kinetic evaluation of an integrated anaerobic-aerobic bioreactor in the treatment of palm oil mill effluent. Environ. Technol. 2017, 38, 1005-1021. [CrossRef] [PubMed]

2. Musa, N.S.; Ahmad, W.A. Chemical oxygen demand reduction in industrial wastewater using locally isolated bacteria. Malays. J. Fundam. Appl. Sci. 2010, 6. [CrossRef]

3. Braun, R.; Wellinger, A. Potential of Co-Digestion; IEA: Paris, France, 2002.

4. Mata-Alvarez, J.; Mace, S.; Llabres, P. Anaerobic digestion of organic solid wastes. An overview of research achievements and perspectives. Bioresour. Technol. 2000, 74, 3-16. [CrossRef]

5. Long, J.H.; Aziz, T.N.; Francis III, L.; Ducoste, J.J. Anaerobic co-digestion of fat, oil, and grease (FOG): A review of gas production and process limitations. Process Saf. Environ. Prot. 2012, 90, 231-245. [CrossRef]

6. Sawatdeenarunat, C.; Surendra, K.; Takara, D.; Oechsner, H.; Khanal, S.K. Anaerobic digestion of lignocellulosic biomass: Challenges and opportunities. Bioresour. Technol. 2015, 178, 178-186. [CrossRef] [PubMed]

7. Wan, C.; Zhou, Q.; Fu, G.; Li, Y. Semi-continuous anaerobic co-digestion of thickened waste activated sludge and fat, oil and grease. Waste Manag. 2011, 31, 1752-1758. [CrossRef] [PubMed]

8. Astals, S.; Nolla-Ardèvol, V.; Mata-Alvarez, J. Anaerobic co-digestion of pig manure and crude glycerol at mesophilic conditions: Biogas and digestate. Bioresour. Technol. 2012, 110, 63-70. [CrossRef] [PubMed]

9. Mao, C.; Feng, Y.; Wang, X.; Ren, G. Review on research achievements of biogas from anaerobic digestion. Renew. Sustain. Energy Rev. 2015, 45, 540-555. [CrossRef]

10. Wu, C.; Li, Y.; Li, W.; Wang, K. Characterizing the distribution of organic matter during composting of sewage sludge using a chemical and spectroscopic approach. RSC Adv. 2015, 5, 95960-95966. [CrossRef]

11. Hallaji, S.M.; Kuroshkarim, M.; Moussavi, S.P. Enhancing methane production using anaerobic co-digestion of waste activated sludge with combined fruit waste and cheese whey. BMC Biotechnol. 2019, 19, 19. [CrossRef]

12. Rabii, A.; Aldin, S.; Dahman, Y.; Elbeshbishy, E. A review on anaerobic co-digestion with a focus on the microbial populations and the effect of multi-stage digester configuration. Energies 2019, 12, 1106. [CrossRef]

13. Campuzano, R.; González-Martínez, S. Characteristics of the organic fraction of municipal solid waste and methane production: A review. Waste Manag. 2016, 54, 3-12. [CrossRef] [PubMed]

14. Dai, X.; Duan, N.; Dong, B.; Dai, L. High-solids anaerobic co-digestion of sewage sludge and food waste in comparison with mono digestions: Stability and performance. Waste Manag. 2013, 33, 308-316. [CrossRef]

15. Chow, W.L.; Chan, Y.J.; Chong, M.F. A new energy source from the anaerobic co-digestion (acd) treatment of oleo chemical effluent with glycerin pitch. Asia Pac. J. Chem. Eng. 2015, 10, 556-564. [CrossRef]

16. EPA. Municipal Solid Waste; United States Environmental Protection Agency (EPA): Washington, DC, USA, 1996.

17. Paritosh, K.; Yadav, M.; Mathur, S.; Balan, V.; Liao, W.; Pareek, N.; Vivekanand, V. Organic fraction of municipal solid waste: Overview of treatment methodologies to enhance anaerobic biodegradability. Front. Energy Res. 2018, 6, 75. [CrossRef]

18. Cheng, J.Y.; Chiu, S.L.; Lo, I.M. Effects of moisture content of food waste on residue separation, larval growth and larval survival in black soldier fly bioconversion. Waste Manag. 2017, 67, 315-323. [CrossRef] [PubMed]

19. Cabbai, V.; Ballico, M.; Aneggi, E.; Goi, D. BMP tests of source selected OFMSW to evaluate anaerobic codigestion with sewage sludge. Waste Manag. 2013, 33, 1626-1632. [CrossRef] [PubMed]

20. Appels, L.; Baeyens, J.; Degrève, J.; Dewil, R. Principles and potential of the anaerobic digestion of waste-activated sludge. Prog. Energy Combust. Sci. 2008, 34, 755-781. [CrossRef] 
21. Duan, N.; Dong, B.; Wu, B.; Dai, X. High-solid anaerobic digestion of sewage sludge under mesophilic conditions: Feasibility study. Bioresour. Technol. 2012, 104, 150-156. [CrossRef]

22. Mendez, R.; Lema, J.M.; Soto, M. Treatment of seafood-processing wastewaters in mesophilic and thermophilic anaerobic filters. Water Environ. Res. 1995, 67, 33-45. [CrossRef]

23. Silvestre, G.; Fernández, B.; Bonmatí, A. Addition of crude glycerine as strategy to balance the $\mathrm{C} / \mathrm{N}$ ratio on sewage sludge thermophilic and mesophilic anaerobic co-digestion. Bioresour. Technol. 2015, 193, 377-385. [CrossRef] [PubMed]

24. Cavinato, C.; Bolzonella, D.; Pavan, P.; Fatone, F.; Cecchi, F. Mesophilic and thermophilic anaerobic co-digestion of waste activated sludge and source sorted biowaste in pilot-and full-scale reactors. Renew. Energy 2013, 55, 260-265. [CrossRef]

25. Al bkoor Alrawashdeh, K.; Pugliese, A.; Slopiecka, K.; Pistolesi, V.; Massoli, S.; Bartocci, P.; Bidini, G.; Fantozzi, F. Codigestion of untreated and treated sewage sludge with the organic fraction of municipal solid wastes. Fermentation 2017, 3, 35. [CrossRef]

26. Macias-Corral, M.; Samani, Z.; Hanson, A.; Smith, G.; Funk, P.; Yu, H.; Longworth, J. Anaerobic digestion of municipal solid waste and agricultural waste and the effect of co-digestion with dairy cow manure. Bioresour. Technol. 2008, 99, 8288-8293. [CrossRef] [PubMed]

27. Li, J.; Jha, A.K.; He, J.; Ban, Q.; Chang, S.; Wang, P. Assessment of the effects of dry anaerobic co-digestion of cow dung with waste water sludge on biogas yield and biodegradability. Int. J. Phys. Sci. 2011, 6, 3679-3688.

28. Silvestre, G.; Bonmatí, A.; Fernández, B. Optimisation of sewage sludge anaerobic digestion through co-digestion with OFMSW: Effect of collection system and particle size. Waste Manag. 2015, 43, 137-143. [CrossRef]

29. Kim, H.-W.; Nam, J.-Y.; Shin, H.-S. A comparison study on the high-rate co-digestion of sewage sludge and food waste using a temperature-phased anaerobic sequencing batch reactor system. Bioresour. Technol. 2011, 102, 7272-7279. [CrossRef]

30. Di Maria, F.; Micale, C.; Contini, S. Energetic and environmental sustainability of the co-digestion of sludge with bio-waste in a life cycle perspective. Appl. Energy 2016, 171, 67-76. [CrossRef]

31. Ma, J.; Van Wambeke, M.; Carballa, M.; Verstraete, W. Improvement of the anaerobic treatment of potato processing wastewater in a UASB reactor by co-digestion with glycerol. Biotechnol. Lett. 2008, 30, 861-867. [CrossRef]

32. Astals, S.; Nolla-Ardèvol, V.; Mata-Alvarez, J. Thermophilic co-digestion of pig manure and crude glycerol: Process performance and digestate stability. J. Biotechnol. 2013, 166, 97-104. [CrossRef]

33. Knothe, G.; Krahl, J.; Gerpen, J.V. The Biodiesel Handbook, 2nd ed.; AOCS Press: Urbana, IL, USA, 2010.

34. Anuar, M.R.; Abdullah, A.Z. Challenges in biodiesel industry with regards to feedstock, environmental, social and sustainability issues: A critical review. Renew. Sustain. Energy Rev. 2016, 58, 208-223. [CrossRef]

35. Monteiro, M.R.; Kugelmeier, C.L.; Pinheiro, R.S.; Batalha, M.O.; da Silva César, A. Glycerol from biodiesel production: Technological paths for sustainability. Renew. Sustain. Energy Rev. 2018, 88, 109-122. [CrossRef]

36. Pinheiro, R.S. Processos de Inovação Tecnológica Para a Glicerina Produzida no Processo de Obtenção de Biodiesel no Brasil; Universidade Federal de Sao Carlos: Sao Carlos, Brazil, 2011.

37. Aguilar-Aguilar, F.A.; Nelson, D.L.; Pantoja, L.d.A.; Santos, A. Study of anaerobic co-digestion of crude glycerol and swine manure for the production of biogas. Rev. Virtual Quim 2017, 9, 2383-2403. [CrossRef]

38. Fountoulakis, M.; Petousi, I.; Manios, T. Co-digestion of sewage sludge with glycerol to boost biogas production. Waste Manag. 2010, 30, 1849-1853. [CrossRef] [PubMed]

39. Rivero, M.; Solera, R.; Perez, M. Anaerobic mesophilic co-digestion of sewage sludge with glycerol: Enhanced biohydrogen production. Int. J. Hydrog. Energy 2014, 39, 2481-2488. [CrossRef]

40. Dos Santos Ferreira, J.; Volschan, I.; Cammarota, M.C. Co-digestion of sewage sludge with crude or pretreated glycerol to increase biogas production. Environ. Sci. Pollut. Res. 2018, 25, 21811-21821. [CrossRef] [PubMed]

41. Razaviarani, V.; Buchanan, I.D.; Malik, S.; Katalambula, H. Pilot scale anaerobic co-digestion of municipal wastewater sludge with biodiesel waste glycerin. Bioresour. Technol. 2013, 133, 206-212. [CrossRef] [PubMed]

42. Nartker, S.; Ammerman, M.; Aurandt, J.; Stogsdil, M.; Hayden, O.; Antle, C. Increasing biogas production from sewage sludge anaerobic co-digestion process by adding crude glycerol from biodiesel industry. Waste Manag. 2014, 34, 2567-2571. [CrossRef] [PubMed] 
43. Jensen, P.; Astals, S.; Lu, Y.; Devadas, M.; Batstone, D. Anaerobic codigestion of sewage sludge and glycerol, focusing on process kinetics, microbial dynamics and sludge dewaterability. Water Res. 2014, 67, 355-366. [CrossRef]

44. Obi, F.; Ugwuishiwu, B.; Nwakaire, J. Agricultural waste concept, generation, utilization and management. Niger. J. Technol. 2016, 35, 957-964. [CrossRef]

45. MacLellan, J.; Chen, R.; Kraemer, R.; Zhong, Y.; Liu, Y.; Liao, W. Anaerobic treatment of lignocellulosic material to co-produce methane and digested fiber for ethanol biorefining. Bioresour. Technol. 2013, 130, 418-423. [CrossRef] [PubMed]

46. Yue, Z.; Teater, C.; MacLellan, J.; Liu, Y.; Liao, W. Development of a new bioethanol feedstock-anaerobically digested fiber from confined dairy operations using different digestion configurations. Biomass Bioenergy 2011, 35, 1946-1953. [CrossRef]

47. Nayal, F.S.; Mammadov, A.; Ciliz, N. Environmental assessment of energy generation from agricultural and farm waste through anaerobic digestion. J. Environ. Manag. 2016, 184, 389-399. [CrossRef] [PubMed]

48. Xie, S.; Wickham, R.; Nghiem, L.D. Synergistic effect from anaerobic co-digestion of sewage sludge and organic wastes. Int. Biodeterior. Biodegrad. 2017, 116, 191-197. [CrossRef]

49. Maragkaki, A.; Fountoulakis, M.; Gypakis, A.; Kyriakou, A.; Lasaridi, K.; Manios, T. Pilot-scale anaerobic co-digestion of sewage sludge with agro-industrial by-products for increased biogas production of existing digesters at wastewater treatment plants. Waste Manag. 2017, 59, 362-370. [CrossRef] [PubMed]

50. Maragkaki, A.; Fountoulakis, M.; Kyriakou, A.; Lasaridi, K.; Manios, T. Boosting biogas production from sewage sludge by adding small amount of agro-industrial by-products and food waste residues. Waste Manag. 2018, 71, 605-611. [CrossRef] [PubMed]

51. Alagöz, B.A.; Yenigün, O.; Erdinçler, A. Ultrasound assisted biogas production from co-digestion of wastewater sludges and agricultural wastes: Comparison with microwave pre-treatment. Ultrason. Sonochem. 2018, 40, 193-200. [CrossRef]

52. Szaja, A.; Montusiewicz, A. Enhancing the co-digestion efficiency of sewage sludge and cheese whey using brewery spent grain as an additional substrate. Bioresour. Technol. 2019, 291, 121863. [CrossRef]

53. Montañés, R.; Pérez, M.; Solera, R. Mesophilic anaerobic co-digestion of sewage sludge and a lixiviation of sugar beet pulp: Optimisation of the semi-continuous process. Bioresour. Technol. 2013, 142, 655-662. [CrossRef]

54. Alagöz, B.A.; Yenigün, O.; Erdinçler, A. Enhancement of anaerobic digestion efficiency of wastewater sludge and olive waste: Synergistic effect of co-digestion and ultrasonic/microwave sludge pre-treatment. Waste Manag. 2015, 46, 182-188. [CrossRef]

55. Salama, E.-S.; Saha, S.; Kurade, M.B.; Dev, S.; Chang, S.W.; Jeon, B.-H. Recent trends in anaerobic co-digestion: Fat, oil, and grease (FOG) for enhanced biomethanation. Prog. Energy Combust. Sci. 2019, 70, $22-42$. [CrossRef]

56. Fonda, K.D.; Hetherington, M.; Kawamoto, M.H. Dealing with FOG: A problem or an opportunity. Proc. Water Environ. Fed. 2003, 2003, 654-678. [CrossRef]

57. Kabouris, J.C.; Tezel, U.; Pavlostathis, S.G.; Engelmann, M.; Todd, A.C.; Gillette, R.A. The anaerobic biodegradability of municipal sludge and fat, oil, and grease at mesophilic conditions. Water Environ. Res. 2008, 80, 212-221. [CrossRef] [PubMed]

58. Masse, L.; Masse, D.; Kennedy, K.; Chou, S. Neutral fat hydrolysis and long-chain fatty acid oxidation during anaerobic digestion of slaughterhouse wastewater. Biotechnol. Bioeng. 2002, 79, 43-52. [CrossRef] [PubMed]

59. Cavaleiro, A.J.; Salvador, A.F.; Alves, J.I.; Alves, M. Continuous high rate anaerobic treatment of oleic acid based wastewater is possible after a step feeding start-up. Environ. Sci. Technol. 2009, 43, 2931-2936. [CrossRef] [PubMed]

60. Madigan, M.T.; Martinko, J.M.; Parker, J.; Brock, T.D. Brock Biology of Microorganisms, 11th ed.; Prentice Hall: Upper Saddle River, NJ, USA, 2006.

61. Pavlostathis, S.; Giraldo-Gomez, E. Kinetics of anaerobic treatment: A critical review. Crit. Rev. Environ. Sci. Technol. 1991, 21, 411-490. [CrossRef]

62. Canakci, M.; Van Gerpen, J. Biodiesel production from oils and fats with high free fatty acids. Trans. ASAE 2001, 44, 1429. [CrossRef]

63. Jeganathan, J.; Nakhla, G.; Bassi, A. Long-term performance of high-rate anaerobic reactors for the treatment of oily wastewater. Environ. Sci. Technol. 2006, 40, 6466-6472. [CrossRef] 
64. Luostarinen, S.; Luste, S.; Sillanpää, M. Increased biogas production at wastewater treatment plants through co-digestion of sewage sludge with grease trap sludge from a meat processing plant. Bioresour. Technol. 2009, 100, 79-85. [CrossRef]

65. Girault, R.; Bridoux, G.; Nauleau, F.; Poullain, C.; Buffet, J.; Peu, P.; Sadowski, A.; Béline, F. Anaerobic co-digestion of waste activated sludge and greasy sludge from flotation process: Batch versus CSTR experiments to investigate optimal design. Bioresour. Technol. 2012, 105, 1-8. [CrossRef]

66. Pereira, M.; Pires, O.; Mota, M.; Alves, M. Anaerobic biodegradation of oleic and palmitic acids: Evidence of mass transfer limitations caused by long chain fatty acid accumulation onto the anaerobic sludge. Biotechnol. Bioeng. 2005, 92, 15-23. [CrossRef]

67. Rinzema, A. Anaerobic Treatment of Wastewater with High Concentrations of Lipids or Sulfate; Staff: Wageningen, The Netherlands, 1988.

68. Kuang, Y. Enhancing Anaerobic Degradation of Lipids in Wastewater by Addition of Co-Substrate; Murdoch University: Perth, Australia, 2002.

69. Davidsson, Å.; Lövstedt, C.; la Cour Jansen, J.; Gruvberger, C.; Aspegren, H. Co-digestion of grease trap sludge and sewage sludge. Waste Manag. 2008, 28, 986-992. [CrossRef]

70. Kabouris, J.C.; Tezel, U.; Pavlostathis, S.G.; Engelmann, M.; Dulaney, J.A.; Todd, A.C.; Gillette, R.A. Mesophilic and thermophilic anaerobic digestion of municipal sludge and fat, oil, and grease. Water Environ. Res. 2009, 81, 476-485. [CrossRef]

71. Silvestre, G.; Rodríguez-Abalde, A.; Fernández, B.; Flotats, X.; Bonmatí, A. Biomass adaptation over anaerobic co-digestion of sewage sludge and trapped grease waste. Bioresour. Technol. 2011, 102, 6830-6836. [CrossRef]

72. Silvestre, G.; Illa, J.; Fernández, B.; Bonmatí, A. Thermophilic anaerobic co-digestion of sewage sludge with grease waste: Effect of long chain fatty acids in the methane yield and its dewatering properties. Appl. Energy 2014, 117, 87-94. [CrossRef]

73. Alqaralleh, R.M.; Kennedy, K.; Delatolla, R.; Sartaj, M. Thermophilic and hyper-thermophilic co-digestion of waste activated sludge and fat, oil and grease: Evaluating and modeling methane production. J. Environ. Manag. 2016, 183, 551-561. [CrossRef]

74. Grady, C.L., Jr.; Daigger, G.T.; Love, N.G.; Filipe, C.D. Biological Wastewater Treatment, 3rd ed.; CRC Press: Boca Raton, FL, USA, 2011.

75. Stafford, D. The effects of mixing and volatile fatty acid concentrations on anaerobic digester performance. Biomass 1982, 2, 43-55. [CrossRef]

76. Karim, K.; Hoffmann, R.; Klasson, K.T.; Al-Dahhan, M. Anaerobic digestion of animal waste: Effect of mode of mixing. Water Res. 2005, 39, 3597-3606. [CrossRef]

77. Rizk, M.C.; Bergamasco, R.; Tavares, C.R.G. Anaerobic co-digestion of fruit and vegetable waste and sewage sludge. Int. J. Chem. React. Eng. 2007, 5. [CrossRef]

78. Stroot, P.G.; McMahon, K.D.; Mackie, R.I.; Raskin, L. Anaerobic codigestion of municipal solid waste and biosolids under various mixing conditions-I. Digester performance. Water Res. 2001, 35, 1804-1816. [CrossRef]

79. Latha, K.; Velraj, R.; Shanmugam, P.; Sivanesan, S. Mixing strategies of high solids anaerobic co-digestion using food waste with sewage sludge for enhanced biogas production. J. Clean. Prod. 2019, 210, 388-400. [CrossRef]

80. Wang, M.; Sun, X.; Li, P.; Yin, L.; Liu, D.; Zhang, Y.; Li, W.; Zheng, G. A novel alternate feeding mode for semi-continuous anaerobic co-digestion of food waste with chicken manure. Bioresour. Technol. 2014, 164, 309-314. [CrossRef]

81. Mahmoodi-Eshkaftaki, M.; Ebrahimi, R. Assess a new strategy and develop a new mixer to improve anaerobic microbial activities and clean biogas production. J. Clean. Prod. 2019, 206, 797-807. [CrossRef]

82. Monnet, F. An introduction to anaerobic digestion of organic wastes. Remade Scotl. 2003, 379, 1-48.

83. Heo, N.H.; Park, S.C.; Kang, H. Effects of mixture ratio and hydraulic retention time on single-stage anaerobic co-digestion of food waste and waste activated sludge. J. Environ. Sci. Health Part A 2004, 39, 1739-1756. [CrossRef]

84. Hagos, K.; Zong, J.; Li, D.; Liu, C.; Lu, X. Anaerobic co-digestion process for biogas production: Progress, challenges and perspectives. Renew. Sustain. Energy Rev. 2017, 76, 1485-1496. [CrossRef]

85. Siddique, M.N.I.; Wahid, Z.A. Achievements and perspectives of anaerobic co-digestion: A review. J. Clean. Prod. 2018, 194, 359-371. [CrossRef] 
86. Khalid, A.; Arshad, M.; Anjum, M.; Mahmood, T.; Dawson, L. The anaerobic digestion of solid organic waste. Waste Manag. 2011, 31, 1737-1744. [CrossRef]

87. Li, Y.; Sasaki, H.; Yamashita, K.; Seki, K.; Kamigochi, I. High-rate methane fermentation of lipid-rich food wastes by a high-solids co-digestion process. Water Sci. Technol. 2002, 45, 143-150. [CrossRef]

88. Lee, M.; Hidaka, T.; Hagiwara, W.; Tsuno, H. Comparative performance and microbial diversity of hyperthermophilic and thermophilic co-digestion of kitchen garbage and excess sludge. Bioresour. Technol. 2009, 100, 578-585. [CrossRef]

89. Hansen, K.H.; Angelidaki, I.; Ahring, B.K. Anaerobic digestion of swine manure: Inhibition by ammonia. Water Res. 1998, 32, 5-12. [CrossRef]

90. Fountoulakis, M.; Manios, T. Enhanced methane and hydrogen production from municipal solid waste and agro-industrial by-products co-digested with crude glycerol. Bioresour. Technol. 2009, 100, 3043-3047. [CrossRef]

91. Vindis, P.; Mursec, B.; Janzekovic, M.; Cus, F. The impact of mesophilic and thermophilic anaerobic digestion on biogas production. J. Achiev. Mater. Manuf. Eng. 2009, 36, 192-198.

92. Ghatak, M.; Mahanata, P. Effect of Temperature on Biogas Production from Rice Straw and Rice Husk. In IOP Conference Series: Materials Science and Engineering; IOP Publishing: Bristol, UK, 2018.

93. Zeeman, G.; Wiegant, W.; Koster-Treffers, M.; Lettinga, G. The influence of the total-ammonia concentration on the thermophilic digestion of cow manure. Agric. Wastes 1985, 14, 19-35. [CrossRef]

94. Hanaki, K.; Matsuo, T.; Nagase, M. Mechanism of inhibition caused by long-chain fatty acids in anaerobic digestion process. Biotechnol. Bioeng. 1981, 23, 1591-1610. [CrossRef]

95. Hwu, C.-S.; Lettinga, G. Acute toxicity of oleate to acetate-utilizing methanogens in mesophilic and thermophilic anaerobic sludges. Enzym. Microb. Technol. 1997, 21, 297-301. [CrossRef]

96. Kim, S.-H.; Han, S.-K.; Shin, H.-S. Feasibility of biohydrogen production by anaerobic co-digestion of food waste and sewage sludge. Int. J. Hydrog. Energy 2004, 29, 1607-1616. [CrossRef]

97. Babaee, A.; Shayegan, J. Effect of organic loading rates (OLR) on production of methane from anaerobic digestion of vegetables waste. In Proceedings of the World Renewable Energy Congress-Sweden, Linkoping, Sweden, 8-13 May 2011; pp. 411-417.

98. Mata-Alvarez, J.; Llabrés, P.; Cecchi, F.; Pavan, P. Anaerobic digestion of the Barcelona central food market organic wastes: Experimental study. Bioresour. Technol. 1992, 39, 39-48. [CrossRef]

99. Ford, M.; Fleming, R. Mechanical solid-liquid separation of livestock manure. Literature review. In Report to Ontario Pork, Case Study; University of Guelph: Ridgetown, ON, Canada, 2002.

100. Massé, D.; Croteau, F.; Masse, L. The fate of crop nutrients during digestion of swine manure in psychrophilic anaerobic sequencing batch reactors. Bioresour. Technol. 2007, 98, 2819-2823. [CrossRef]

101. Tu, Q. Fats, Oils and Greases to Biodiesel: Technology Development and Sustainability Assessment; University of Cincinnati: Cincinnati, OH, USA, 2015.

102. Tu, Q.; McDonnell, B.E. Monte Carlo analysis of life cycle energy consumption and greenhouse gas (GHG) emission for biodiesel production from trap grease. J. Clean. Prod. 2016, 112, 2674-2683. [CrossRef]

103. Wallace, T.; Gibbons, D.; O'Dwyer, M.; Curran, T.P. International evolution of fat, oil and grease (FOG) waste management-A review. J. Environ. Manag. 2017, 187, 424-435. [CrossRef]

(C) 2020 by the authors. Licensee MDPI, Basel, Switzerland. This article is an open access article distributed under the terms and conditions of the Creative Commons Attribution (CC BY) license (http://creativecommons.org/licenses/by/4.0/). 